\title{
Jurnal Teknologi Reaktor Nuklir

\section{A Preliminary Assessment of the Effects of Drought on Water Sustainability Indicators for Nuclear Power Generation in Mongolia}

\author{
Ichinkhorloo Davaadorj $^{1}$, Eric Yee ${ }^{2, *}$, and Restu Maerani ${ }^{3}$ \\ ${ }^{1}$ Consultant, Ulaanbaatar, Mongolia \\ ${ }^{2}$ KEPCO International Nuclear Graduate School, Department of NPP Engineering,. 658-91 Haemaji-ro, Seosaengmyeon, Ulju-gun, Ulsan 45014, \\ Republic of Korea \\ ${ }^{3}$ Center for Nuclear Reactor Technology and Safety, National Nuclear Energy Agency of Indonesia (BATAN), Kawasan Puspiptek Serpong Gd. 80 \\ Tangerang Selatan 15310, Indonesia
}

\section{ARTICLE INFO}

Article history:

Received: 6 June 2019

Received in revised form: 24 June 2019

Accepted: 25 June 2019

\section{Keywords:}

nuclear

sustainability

water

drought

\begin{abstract}
A B S T R A C T
As the effects of climate change are being felt all over the world, sustainability indicators such as water withdrawn per kilowatt-hour, are becoming more important in the decision-making process for large infrastructure projects. In Mongolia, we are deciding whether to use nuclear as a main power source. However, local droughts in Mongolia can be quite severe, occurring every 4-5 years and several countries have shown droughts to interrupt their power plant operations. This study collects data and conducts analyses to estimate sustainability indicators for a nuclear power plant life cycle and extends these analyses to understand how an event such as a drought would affect such indicators. The first part of this study is to provide background information regarding life cycle water use from power generation facilities. Our study focused on the APR-1400 nuclear power plant. If we account for drought frequency in Mongolia, the life cycle water withdrawal is estimated to be approximately $7,611 \mathrm{~L} / \mathrm{MWh}$ for the nuclear power plant.
\end{abstract}

\section{INTRODUCTION}

As the effects of climate change are being felt all over the world, sustainability indicators such as carbon dioxide equivalent per kilowatt-hour, $\mathrm{CO}_{2-}$ eq $/ \mathrm{kwh}$, or water withdrawn per kilowatt-hour, $\mathrm{H}_{2} \mathrm{O}_{\mathrm{wd}} / \mathrm{kwh}$, are becoming more important in the decision making process for large infrastructure projects. In Mongolia, we are deciding whether to use nuclear or hydro as a main power source. However, local droughts in Mongolia can be quite severe and several countries have shown droughts to interrupt nuclear and hydro power plant operations. This is especially important as Mongolia has been considering developing a

\footnotetext{
* Corresponding author

E-mail: eric.yee@kings.ac.kr

DOI: $10.17146 / \mathrm{tdm} \cdot 2019.21 .2 .5455$
}

nuclear power program. This study collects data and conducts analyses to estimate certain sustainability indicators for nuclear and hydro power plant life cycles, and extend these analyses to understand how an event such as a drought would affect such indicators.

Mongolia is located in a very sensitive area. The southern part of the territory is desert and the northern part is Taiga forest covers. At present, the winter climate is dominated by the Siberian high, whereas the summer climate is dominated by the Asian low. Mongolia's climate is characterized by long and cold winters, dry, hot summers, low precipitation, and high temperature fluctuations. There is limited precipitation occurring mostly in June, July, and August. The average air temperature in July is less than $15^{\circ} \mathrm{C}$ in the Altai, Khangai, Khuvsgul, and Khentii mountainous areas; $15-20^{\circ} \mathrm{C}$ 
in the valleys of mountainous areas, and $20-25{ }^{\circ} \mathrm{C}$ in the southern part of the Eastern steppe and the Gobi desert. The highest recorded temperature was $44^{\circ} \mathrm{C}$, observed at Khongor soum of Darkhan-Uul aimag on 24 July, 1999. Annual mean precipitation is $300-400 \mathrm{~mm}$ in the Khangai, Khentein and Khuvsgul mountainous region, $150-250 \mathrm{~mm}$ in the steppes, $100-150 \mathrm{~mm}$ in the steppe-desert, and 50 $100 \mathrm{~mm}$ in the Gobi-desert. About $85 \%$ of total precipitation falls from April to September, of which about $50-60 \%$ falls in July and August.

The number of hottest days has increased by 8 18 days, depending on geography. Greater increases, 15-18 days, have been found in the Khan-Khokhii mountainous region of the Great Lakes Basin and in the western part of the Khangain mountains. The Mongolian climate is getting warmer and slightly drier. Warming is most pronounced in the high mountainous areas and their valleys, and least in the Gobi desert. Precipitation has tended to decrease slightly. Although air temperature is rapidly increasing during the warmer season, the precipitation is not increasing at the same pace. This has led to increased aridity and ongoing drought processes in Mongolia. Drought is associated with a lack of precipitation and often high temperatures that contribute to drying. As a result of the several droughts from 1999 to 2007, more than 3,000 water sources including 680 rivers and 760 lakes, have dried up. Such large scale environmental degradation in turn has affected the level of agricultural products and energy output from hydropower plants. A dry summer and drought has been observed to decrease pasture productivity by 12 to $48 \%$ in the high mountains and 28 to $60 \%$ in the Gobi desert-steppe regions [1]. A large-scale drought has generally occurred every 25-30 years, while smaller, more localized droughts occurred once every 4-5 years. Figure 1 shows the distribution of drought frequency in Mongolia. Estimation of the effects of global warming on water resources in a region or in a river basin are required by decision makers to prevent negative effects [1]. There are also limited water resources and on average, approximately $22,300 \mathrm{~m}^{3}$ of water belongs to each $1 \mathrm{~km}^{2}$ of area. Total water resources are $38.8 \mathrm{~km}^{3} /$ year, where potential exploitable water resources are $34.6 \mathrm{~km}^{3} /$ year. Of the exploitable water resources, $82.4 \%$ belong to surface water resources. Since there are limited water resources in Mongolia, the selection of the most suitable cooling system of new nuclear power plants (NPPs) is a very important factor in the decision making process.

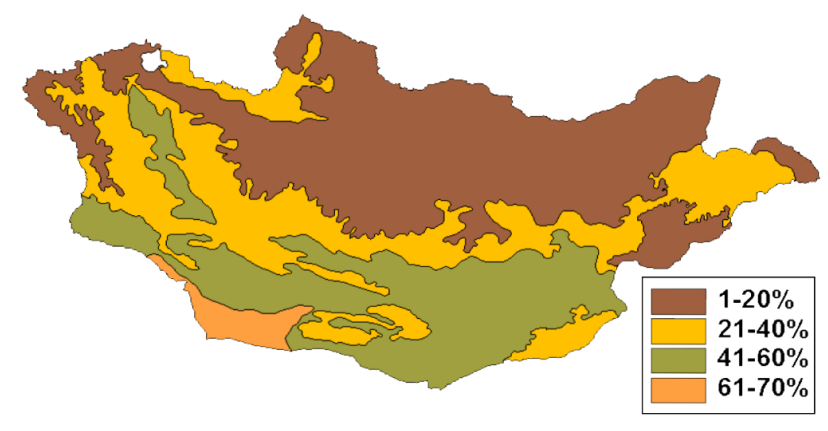

Fig. 1. Distribution of drought frequency in Mongolia.

\section{COOLING OPTIONS}

Drought can have many devastating effects on communities and the surrounding environment. Most power plants which use water such as hydropower, coal, and NPPs may need to be shut down or have capacity curtailments. General impacts of drought and high temperatures on power plants include limited amounts of withdrawn water due to low water levels, exposed water intake structures, lower plant efficiency due to warmer cooling water, and warmer than expected discharge water. Additionally, in certain power environments, electric power production costs and emissions will increase from the use of natural gas as a substitute source. During the summer of 2007, the southeast region of the United States faced a very severe drought forcing nuclear and coal-fired plants to shut down. In France, NPPs loss 7-15\% of capacity for 5 weeks, and hydro power plants lost $20 \%$ of capacity in 2003. In mid-2010 the Tennessee Valley Authority had to reduce power at its three Browns Ferry units in Alabama to $50 \%$ in order to keep river water temperatures below $32^{\circ} \mathrm{C}$, at a cost of some $\$ 50$ million to customers.

The main use of water in NPPs is for the cooling system to condense steam and remove waste heat. The magnitude of waste heat is significant. Since 1882 , the power industry has developed a variety of cooling systems for dissipating waste heat from thermal power plants. There are two fundamental cooling systems: once through and closed loop cooling.

In the once through system, as shown in Figure 2, cooling water from nearby sources, such as a river, lake, or an ocean, are used to condensate the steam from the power plant. This cooling water is then returned to the originating water body. The main disadvantage of a once through system is it requires withdrawing large amounts of water, but returns almost all of the used water to its source which would raise the originating water body's 
temperature. In some cases this temperature rise may affect the local ecology. There are regulations that set the maximum allowable temperature increase to minimize environmental impacts. For instance, at the Bugey nuclear power station, the maximum increase in water temperature during the summer is normally $7.5{ }^{\circ} \mathrm{C}$, but $5.5{ }^{\circ} \mathrm{C}$ in the summer. The power station has a maximum discharge temperature of $30{ }^{\circ} \mathrm{C}$, but $34{ }^{\circ} \mathrm{C}$ in the summer, with a maximum downstream temperature of $24{ }^{\circ} \mathrm{C}$, but $26^{\circ} \mathrm{C}$ is allowed for up to 35 summer days. For plants using direct cooling from the sea, the allowed temperature increase offshore is $15^{\circ} \mathrm{C}$. This type of cooling system also has many advantages, such as being a simple system and relatively inexpensive.

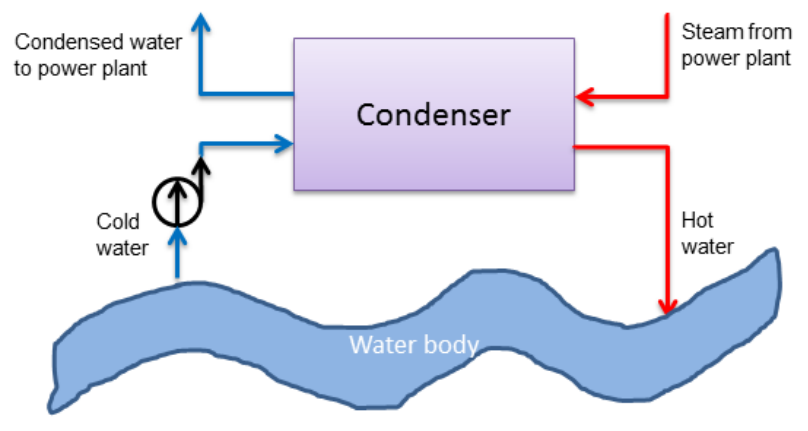

Fig. 2. Diagram of once through cooling system.

In a cooling tower system, the water is cooled by contact with air, with a schematic shown in Figure 3. Some of the water is evaporated and most is sent back to the condenser to condense the steam. Hot water from the condenser is sprayed through pressurized nozzles near the top of the cooling tower, which forms small droplets, while air comes up from the bottom of the tower and into the atmosphere. The cooled water is collected at the bottom of the cooling tower and back to the condenser to condense steam. Due to evaporation of the cooling water after each loop, the water may have a higher concentration of minerals and dissolved suspended solids. This water is discharged and replaced with clean water.

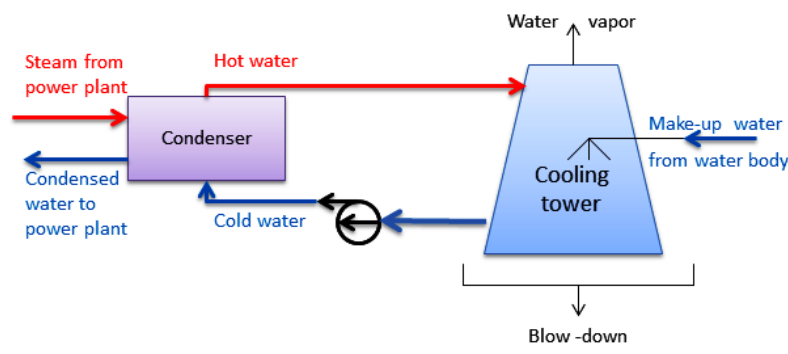

Fig. 3. Diagram of cooling tower system.

There are two basic designs for recirculating cooling towers system: natural and mechanical draft. Natural draft towers remove the heat from the tower to outside air up through the tower, either in a cross-flow or counter-flow pattern. These towers do not require fans and have low operating but significant maintenance costs. Mechanical draft fans force ambient air through the tower either in cross-flow or counter-flow patterns. Efficiency is higher due to large temperature differentials and has lower maintenance costs relative to natural draft cooling towers. However, they have the disadvantage of requiring auxiliary power, typically about $1-1.2 \%$ of the plant's output.

There are also combined, or hybrid, cooling tower systems, where the hybrid cooling tower can be operated either as a pure wet cooling tower or as a combined wet/dry cooling tower, depending on the ambient air temperature. Cooling tower plumes have the potential for causing or increasing local fogging or icing condition. Advantages are less space requirement and less water use. Additionally, power plants with cooling towers can be located at distances from the water body. Cooling towers with recirculating water reduce the overall efficiency of a power plant by $2-5 \%$ compared with oncethrough systems, with the actual amount depending on local conditions. A 2009 US DOE study states hybrid cooling towers are about $40 \%$ more expensive than a direct, once-through cooling system [2].

A cooling pond system uses a large water pond to remove waste heat through evaporation, convection, and radiation with a schematic shown in Figure 4. It can be a natural lake or a man-made reservoir, which can be used for purposes other than cooling, such as controlled fisheries. The design of a cooling pond depends upon the plant size, the local meteorology, and the pond type. Cooling ponds require large areas. Additionally, cooling ponds have potential for increasing local fogging and icing, however there is limited information concerning the fogging potential of cooling ponds. Ponds do demonstrate a stem fog 
directly over the cooling pond surface during cold weather periods, although experience has suggested that this fog will not extend over the land surrounding the pond for more than a few yards. The potential for cooling pond fogging and icing increases as the air temperature decreases, the humidity increases, and atmospheric stability increases. Another type of cooling pond is a spray cooling pond. Cooling is done through evaporative and convective heat exchange between the spray droplets and the ambient air.

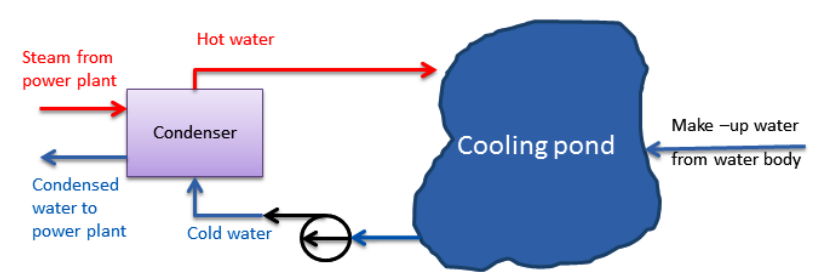

Fig. 4. Diagram of cooling pond system.

Dry cooling systems use air instead of water for cooling with a schematic shown in Figure 5. Therefore, this type of cooling system does not withdraw or consume any water for cooling purpose. It has minimal environmental impacts relative to the other cooling systems aforementioned. However, this system requires a large surface area for heat exchanger. Dry cooling systems use approximately $95 \%$ less water than wet recirculating systems and require high capital costs, high auxiliary operating power, and low power plant performance. Thermal efficiency will be high. Dry cooling is not currently used in nuclear power generation due to safety risks of using dry-cooled technology with nuclear reactors and the high costs of operating large dry-cooling fans. A 2009 US DOE study says dry cooling systems are three to four times more expensive than a recirculating wet cooling system [2].

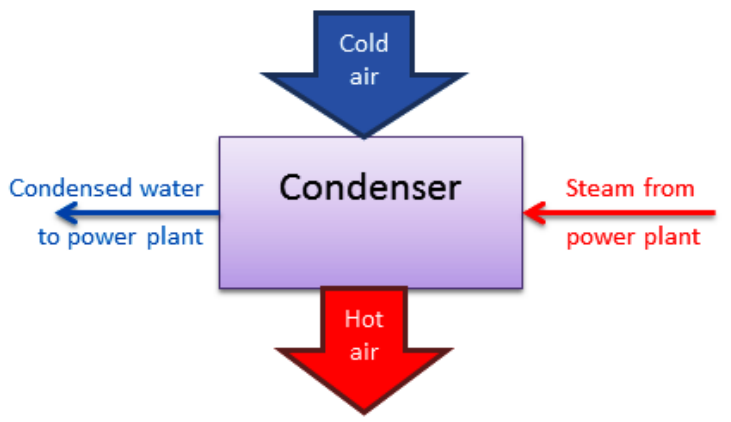

Fig. 5. Diagram of dry cooling system.
The use of melting ice to cool cooling water of power plant has been considered as an alternative approach for high latitude locations, where ice is more readily available. This system has low evaporative losses, high plant efficiency, and no required blow down scheme. One type of ice storage system is the seasonal storage of ice or snow for a large power plant. A large amount of ice can be taken from a river or a lake or just by freezing fresh water during the cold season.

\section{LIFE CYCLE INDICATORS}

This study presents some preliminary analyses to estimate sustainability indicators for nuclear NPP life cycles, with an extension of these analyses to understand how a drought would affect such indicators for Mongolia. The comparisons of power generation technology could be made by per unit of generated energy. Some power plants are utilized at full capacity for most of the year, while others are not available. Some plants are expected to operate for 100 years, while others are expected to operate for 30 years. Therefore, comparisons of power generation technology should be based on the amount of energy produced in its entire life time. The environmental impacts are then compared in terms water use, $\mathrm{L} / \mathrm{MWh}$. The amount of each environmental impact across the entire life cycle to generate net $1 \mathrm{kWh}$ or 1 MWh of electricity is defined as follows:

$$
L C S I=\frac{\sum E I}{Q}
$$

Where LCSI $=$ life cycle sustainability indicator, $\mathrm{EI}=$ environmental impact during lifetime of power plant, $\mathrm{Q}=$ net output of electricity during a lifetime of power plant. The indicators for water usage are separated into two categories: (i) consumptive water use, the portion of water withdrawn that is evaporated, transpired, incorporated into products or crops, consumed by humans or livestock, or otherwise removed from the immediate water environment, and (ii) water withdrawal, water removed from the ground or diverted from a surface-water source for use [3]. This relationship is applied over the nuclear fuel life cycle, which in our study is indicated in Figure 6. 


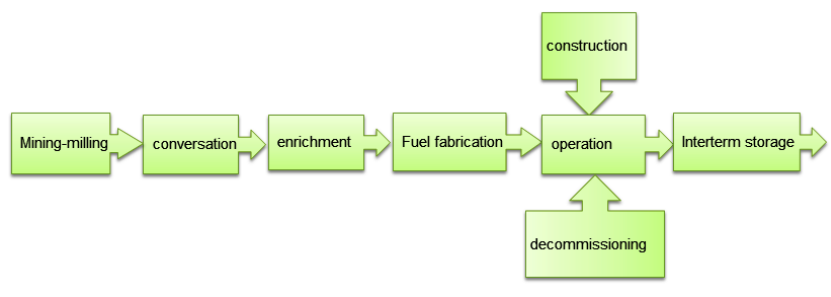

Fig. 6. Nuclear power plant's fuel cycle system boundary.

The nuclear fuel cycle is divided into two classes, open and closed. The once-through cycle is the simplest. It requires uranium ore as input, milling and purification of natural uranium, conversion of the uranium to a chemical form suitable for enrichment, enrichment of the uranium U-235 isotope, fuel fabrication, loading of uranium fuel assemblies in a reactor, and then reactor operation. At the end of its useful life, spent fuel is removed from the reactor, stored in a pool of water for cooling and shielding of radioactivity, then removed and placed in air-cooled casks at reactor sites for interim storage, and finally removed to geologic waste storage facilities for permanent storage. Long term isolation and heat removal from spent fuel is necessary to prevent release of radioactive isotopes to groundwater near a repository. Spent fuel fission product radioactive decay and heat generation continues for hundreds of years, and in smaller quantities for many thousands of years. Boiling water reactors, BWRs, differ from light water reactors, LWRs, principally in that the fuel requires lower initial enrichment and achieves lower burnup, which would slightly decrease the required natural uranium feed and slightly increase the mass of spent fuel produced. Pressurized water reactors, PWR, are considered a type of LWR.

Heavy water reactor, HWR, fuel cycles do not require enrichment in U-235. Hence, the conversion and enrichment steps above do not apply for HWRs. However, some HWR operators are considering the use of slightly enriched uranium oxide, UOX, such that some conversion and enrichment would also be required. Yet other advanced HWR schemes involve the direct use of spent LWR UOX fuel after appropriate spent LWR defueling and re-fabrication. While several countries use mixed oxide, MOX, fuel in LWRs, use of MOX is also being investigated for HWRs.

In the modern closed fuel cycle, the spent fuel discharged from the reactor is reprocessed, and the products are partitioned into uranium and plutonium suitable for fabrication into oxide fuel or MOX to be recycled back into a reactor. The rest of the spent fuel is treated as high-level waste, HLW. Recycling of fuel can be done in thermal reactors, or in fast reactors.

The representative plant for current nuclear power in South Korea is the APR1400. The APR1400 NPP has an open fuel cycle. The reactor core of the APR1400 is designed to generate 3,987 MW thermal with an average volumetric power density of $100.9 \mathrm{~W} / \mathrm{cm}^{3}$. The reactor core consists of 241 fuel assemblies. The core is designed for an operating cycle of over 18 months with a discharge burnup as high as 55,000 MWD/MTU. Table 1 shows the typical material balance in a nuclear fuel cycle for the operation of a 1400 MWe nuclear power reactor.

Table 1. Material balance in an APR1400 nuclear fuel cycle.

\begin{tabular}{|c|c|}
\hline $\begin{array}{l}\text { Cooling } \\
\text { system } \\
\text { type }\end{array}$ & Materials \\
\hline Mining & 35,700 tons of $1 \%$ uranium ore \\
\hline Milling & $\begin{array}{l}421 \text { tons of uranium oxide concentrate } \\
\text { (with } 357 \mathrm{t} \mathrm{U} \text { ) }\end{array}$ \\
\hline Conversion & 528 tons $\mathrm{UF}_{6}$ (with $357 \mathrm{t} \mathrm{U}$ ) \\
\hline Enrichment & $\begin{array}{l}57 \text { tones } \mathrm{UF}_{6} \text { (with } 38 \mathrm{t} \text { enriched } \mathrm{U} \text { ) - } \\
\text { balance is 'tails' }\end{array}$ \\
\hline $\begin{array}{l}\text { Fuel } \\
\text { fabrication }\end{array}$ & 43 tones $\mathrm{UO}_{2}$ (with $38 \mathrm{t}$ enriched $\mathrm{U}$ ) \\
\hline $\begin{array}{l}\text { Reactor } \\
\text { operation }\end{array}$ & 9,800 million $\mathrm{kWh}$ of electricity \\
\hline Spent fuel & $\begin{array}{l}38 \text { tones containing } 382 \mathrm{~kg} \text { plutonium, } \\
36.6 \text { tones uranium }(0.8 \% \mathrm{U}-235) \text {, } \\
1,210 \mathrm{~kg} \text { fission products, also transuranic }\end{array}$ \\
\hline
\end{tabular}

\section{ANALYSIS OF WATER USE}

The following sections outline the use of water throughout the major life cycle phases of a NPP [4].

\subsection{MINING AND MILLING}

Water is used in both surface and underground mines for dust suppression and machinery cooling. The water is conveyed by tanker or pipelines, which in large mines may need to be many kilometers long. Most water in mining is for processing and treating the extracted material prior to shipment. In dry-hot climates, evaporation of water stored for future use is also a source of consumption. Restoration of mine sites can also require water to establish new vegetation. A water intensity of 0.1 to 1.5 gallons per MMBTU of ore for open pit mining and 0.5 to 1 gallon per MMBTU for underground mining [5]. These data 
are lower than those by others [6], which could be linked to industrial practices. Additionally, the water intensity of in situ leaching, ISL, (the example is from a mine in Australia) is estimated to be 14.6 gallons per MMBTU of ore.

The milling of uranium can consume about 3 gallons per MMBTU of product almost entirely as evaporation from tailings ponds [6]. For open-pit and underground mined uranium, the ore is first crushed and then ground in large water-filled mills before being leached in acid or alkaline solution. After leaching, the spent material (tailings) can be pumped into old mine workings, if space exists. More frequently it is pumped into tailings ponds. In some mines, uranium is extracted by a process known as 'heap leaching' in which crushed ore is piled into large heaps that are sprayed for months with re-circulated leaching agents. The resulting leachates, from both milling and heap leaching, are passed through ion exchange units to separate out the uranium content, which is precipitated as a concentrate of the uranium oxide $\mathrm{U}_{3} \mathrm{O}_{8}$, historically known as yellowcake.

At in situ leaching, ISL, mines, the separation process circumvents the milling needed for mined ores. The majority $(97-99 \%)$ of the fluid pumped to the surface is normally recycled in continuous ISL cycles after the uranium in the fluid is captured by ion exchange

\subsection{CONVERSION AND ENRICHMENT}

Compared with centrifugation, diffusion requires several thousands of times and large volumes of cooling water to dissipate waste heat. However both types, centrifugal and diffusion, are considered for completeness.

\subsection{CONSUMPTION}

The water from the mines and processing plants must be captured and held in secure tailings ponds so that solids can settle out. The remaining liquids are then disposed of either by natural evaporation or recirculation to the milling operation. In ISL mines, any water withdrawn from the ore body is either evaporated or re-injected. For conversion and enrichment plants that use closedloop cooling, water consumption and withdrawals are approximately equal; for plants that use oncethrough cooling, withdrawals are about 10 times larger than consumption.

\subsection{CONSTRUCTION}

In general, water needs during the construction phase of an NPP are mostly satisfied by drinking water. Water is needed for concrete mixing, backfill moisture adjustment, dust control, potable water for construction personnel, initial fill of circulating water reservoirs, and pre-operational flushing and testing. Typical values of water consumption during construction, approximately 4 5 years, in total are: 10,000 to $40,000 \mathrm{~m}^{3}$ during excavation depending on site characteristics, $355,937 \mathrm{~m}^{3}$ for concrete mixing from $123,307 \mathrm{yd}^{3}$ of cement and 300,000 to $600,000 \mathrm{~m}^{3}$ supply for construction staff depending on the site $[7,8]$.

\subsection{COMMISSIONING}

Starting with commissioning and preoperational tests, water consumption is mainly determined by cleaning, flushing, and initial filling of the plant's operating circuits. The cooling water circuits will be cleaned, flushed and filled with sea or river water from the same source that is planned to be used during plant operation. This can be considered as water withdrawal without significant heat introduction. The values to be considered are determined by the related pump capacities and are the same as for normal operation as these systems typically run at full flow. The common practice in modern plants is to discharge the cleaning and flushing waters, as they contain impurities. The consumption of demineralized water (produced with drinking water) during commissioning can be estimated to be in the range of 20,000 to $30,000 \mathrm{~m}^{3}$ [8]. In addition, drinking and potable water is needed for plant staff. The consumption levels will be similar to those during the plant outage period, as the number of workers is similar. A typical value would be approximately 200 to $400 \mathrm{~m}^{3} / \mathrm{d}$ [8]. Cooling water consumption starts as soon as hot functional tests are performed until the provisional takeover of the plant by the client.

\subsection{OPERATIONS}

Water withdrawal is mainly dominated by the turbine condenser cooling and is therefore independent of the type of reactor. The main influence here is the efficiency of power conversion, which is the factor defining the dissipated heat. High efficiency plants can notably reduce the cooling water demand. Water withdrawal reaches maximum values for open loop cooling, where the cooling water flow represents often more than $95 \%$ of the total water usage. The 
use of cooling towers in closed loop cooling reduces the water withdrawal to the evaporation, blow-down losses, and drift losses which are about $1 \%$ to $4 \%$ of the water flow rate of open loop cooling, but this increases investment and operation costs.

The water usage of the once-through cooling system depends on the size of the nuclear power reactor it services. The minimum flow rate and consumption of water needed in a once-through cooling system is derived from waste heat load, specific hear of water, change in temperature, evaporation amount (taken as 1\% for simplicity) which depends on ambient temperature and wind speed as well [9]. Table 2 lists the parameters used for a $1400 \mathrm{MWe}$ nuclear power reactor.

Table 2. Water use for once through cooling in an APR1400.

\begin{tabular}{lr}
\hline Electrical output & $1,400 \mathrm{MWe}$ \\
Waste heat load & $8.8 \times 10^{9} \mathrm{BTU} / \mathrm{h}$ \\
Plant availability & $90 \%$ \\
Lifetime & 60 years \\
Efficieny & $35 \%$ \\
Cooling flow rate & $65 \mathrm{ton} / \mathrm{s}$ \\
Water withdrawal & $160,000 \mathrm{~L} / \mathrm{MW}$ \\
\hline
\end{tabular}

The performance of cooling towers is evaluated to assess present levels of approach and range against their design values, identify areas of energy waste, and to suggest improvements. Range is the difference between the cooling tower water inlet and outlet temperature. A high cooling tower range means the cooling tower has been able to reduce the water temperature effectively, and is thus performing well. In an open recirculating cooling water system with a heat load, water is constantly leaving the system through evaporation, and intermittently) leaving the system through blowdown. Evaporation rate, ER, represents on average how much pure water is leaving the system through evaporation from the cooling tower. Blowdown, $B D$, is the intentional, controlled removal of mineral-laden water from the cooling system. As pure water evaporates from the cooling system, dissolved solids left behind concentrate in the bulk cooling water. The blowdown rate is quantified by the degree of the concentration of these solids is referred to as the concentration ratio, $C R$, also called the cycles of concentration. The average value for a thermal power plant is $5 . B D$ can be calculated from evaporation and cycles of concentration. $B D$ also includes tower water lost to drift, $D$, which is often negligible. Generally water withdrawal is the sum of $E R, B D$, and $D$. Results for our system are shown in Table 3.

Table 3. Water use for cooling tower.

\begin{tabular}{lr}
\hline Range & $9.5^{\circ} \mathrm{C}$ \\
Concentration ratio & 5 \\
Heat absorption through & 0.8 \\
sensible heat & \\
$E R$ & $12,721 \mathrm{gpm}$ \\
$B D$ & $3,180 \mathrm{gpm}$ \\
$D$ & $1,036 \mathrm{gpm}$ \\
Makeup water & $16,967 \mathrm{gpm}$ \\
Water withdrawal & $2,750 \mathrm{~L} / \mathrm{MW}$ \\
Water consumption & $2,236 \mathrm{~L} / \mathrm{MW}$ \\
\hline
\end{tabular}

A cooling pond system uses a large water pond to remove waste heat through evaporation, convection, and radiation, as shown in Figure 7. However, cooling ponds reduce the evaporative losses of cooling towers, consume more water via evaporation, and require large areas. The heat transfer mechanisms between the water surface and the atmosphere are complicated and we utilize a simple methodology which takes a linear combination of net heat flux input to a water body, short-wave radiation incident to the water surface, net atmospheric radiation from the water surface, back radiation from the water surface, evaporative heat flux from the water surface, and conductive heat flux from the water surface [10]. Table 4 shows the parameters used to estimate cooling pond calculations.

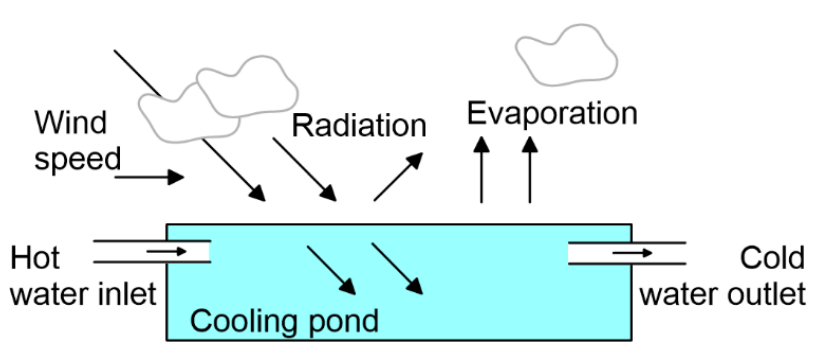

Fig. 7. Cooling pond mechanisms.

Table 4. Water use for cooling pond.

\begin{tabular}{lr}
\hline Ambient temperature & $25^{\circ} \mathrm{C}$ \\
Wind speed & $6.5 \mathrm{~km} / \mathrm{h}$ \\
Relative humidity & $70 \%$ \\
Dew point temperature & $18.9^{\circ} \mathrm{C}$ \\
Area of pond & $9 \mathrm{~km}^{2}$ \\
Cooling pond capacity & 0.54 \\
Water withdrawal & $2,337 \mathrm{~L} / \mathrm{MW}$ \\
Water consumption & $1,869 \mathrm{~L} / \mathrm{MW}$ \\
\hline
\end{tabular}


The non-safety grade component cooling water systems supply all systems in the turbine island which require cooling during normal plant operation. The water source can be shared with the main cooling water for the turbine condenser cooling as the same operational aspects apply. Main sources for heat dissipation during normal plant operation include the spent fuel pool, cooling of components, coolant treatment, and chillers and ventilation systems. The volume of water required for these systems is usually less than 10 percent of the volume required for condenser cooling. Some of these systems are augmented with auxiliary cooling towers to reduce the temperature of the effluent released to the adjacent body of water [10]. During plant operation, the heat to be transported varies but the water withdrawal remains constant as service water pumps are usually operated at constant flow rates. Specific influence on the design comes from safety considerations which lead to functional separation between safety and non-safety component cooling water systems but the water withdrawal remains unaffected, as this is determined by the dissipated heat.

Water is also required for spent fuel systems and processes. These include high and low level waste disposition, long term waste storage, and spent fuel cooling. Wet storage requires a fuel pool cooling system to continually remove all the heat generated by the stored fuel assemblies and thus to maintain a certain pool water temperature. The decay heat is transferred safely from the fuel pool water under all normal and credible abnormal operating conditions to the heat sink. A gigawatt-year of electricity is equivalent to 8,760,000 MWh, which translates to a water demand of $2,740 \mathrm{~L} / \mathrm{MWh}$. On the basis of spent fuel, 2,740 L/MWh is $631,000 \mathrm{~L} / \mathrm{kg}$ of spent fuel. Ninety-nine percent of this water is returned to the source, and thus water consumption (the difference between withdrawal and discharge) is $6,310 \mathrm{~L} / \mathrm{kg}$ of spent fuel [8].

In addition to the use of water for heat dissipation, a NPP also needs water for plant service and operation. Industrial quality and potable water is required for these purposes. NPPs withdraw water from rivers, lakes, groundwater and the public water supply system. The available source of water normally does not fulfill the quality requirements for use in the NPP. Kori Units 3 and 4 obtains potable water from municipal water (Busan Water Authority) and Industrial water from Kwater. In 2008 for example, the quantity of water used in Kori units 3 and 4 during normal operations was about $192,000 \mathrm{~m}^{3} /$ year [8].

\subsection{DECOMMISSIONING}

Cessation of plant operations will result in a significant decrease in water consumption because reactor cooling is no longer required. Although water will still be required for spent fuel cooling, this demand will decrease as the fuel ages. Dewatering systems may remain active during decommissioning of a nuclear facility to control the water pathway for the release of radioactive material. Decommissioning activities that may influence water use include fuel removal, staffing changes, large component removal, decontamination and dismantlement (using highpressure water sprays), structure dismantlement, and entombment.

In summary, the life cycle water use for APR1400 is shown in Table 5

Table 5. Estimated life cycle water use for NPP.

\begin{tabular}{lcc}
\hline \multicolumn{1}{c}{ Process } & $\begin{array}{c}\text { Consumption } \\
\text { (L/MW) }\end{array}$ & $\begin{array}{c}\text { Withdrawal } \\
\text { (L/MW) }\end{array}$ \\
\hline Mining and & $4,172-5,917$ & $4,172-5,917$ \\
milling & 8 & 8 \\
Conversion & 82 & 82 \\
$\begin{array}{l}\text { Centrifugal } \\
\text { enrichment }\end{array}$ & & \\
Diffusion & 10 & 10 \\
enrichment & 0.67 & 0.67 \\
Fuel fabrication & 1.09 & 1.09 \\
Construction & & \\
Operation & & 160,000 \\
$\quad$ Once through & $\mathrm{N} / \mathrm{A}$ & 2,750 \\
\multicolumn{1}{c}{ Cooling tower } & 2,236 & 2,337 \\
$\quad$ Cooling pond & 1,869 & 0.03 \\
Waste & 0.03 &
\end{tabular}

Power plant cooling systems will have an impact on power plant efficiency, capital and operation costs, water consumption, water withdrawal, and environmental impact. To choose an optimal cooling system for a power plant, regional and ambient conditions in addition to existing regulations are very important. A summary of the cooling system tradeoffs are captured Table 6. Although Dry cooling analyses were not conducted, their estimated relative metrics are provided for completeness 
Table 6. Comparison of cooling systems.

\begin{tabular}{cccc}
\hline $\begin{array}{c}\text { Cooling } \\
\text { system type }\end{array}$ & $\begin{array}{c}\text { Water } \\
\text { withdrawal }\end{array}$ & $\begin{array}{c}\text { Water } \\
\text { consumption }\end{array}$ & $\begin{array}{c}\text { Capital } \\
\text { Cost }\end{array}$ \\
\hline Once-through & High & Low & Low \\
Cooling pond & Low & High & Low \\
Cooling tower & Low & High & Low \\
Dry cooling & None & None & High \\
\hline
\end{tabular}

\section{DROUGHT IMPACT ASSESSMENT}

The main impact of drought is its effect on water supply for NPPs. Drought and high temperature can affect nuclear plants in three main ways. One is that NPPs have significant cooling water use, most NPPs are built near the sea, ocean, lakes, or rivers. If water levels drop below the plants' intake pipes due to evaporation, then cooling functions will be halted or jeopardized. Lowering intake pipes is not simple and will be very expensive, taking several months and risking sediment damage to the plant. Second is elevated air temperatures. The temperature of the water body will increase, thus warming. Since the cooling water is warm, the efficiency of the power plant will decrease. The third is the heated outflow of power plants could raise the cooling water body's temperature above accepted levels. That has happened repeatedly in the U.S. and in Europe. If a plant isn't shut down in those situations, the hot discharge can disrupt ecosystem of water body and also increase evaporation. As a result of high temperatures and low humidity, the load of a power power plant may be limited by regulated maximum allowable temperature for return water or by reduced access to water.

An estimate of the performance of the Barakah nuclear power plant using high ocean water temperature and thermal efficiency variations is shown in Figure 8 [11]. In practice, the temperature difference between cooling water and steam is about $10^{\circ} \mathrm{C}$ to $15^{\circ} \mathrm{C}$.

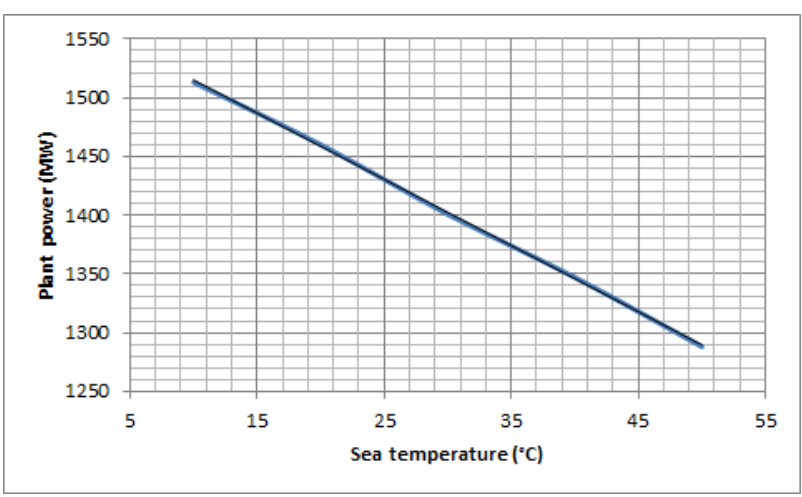

Fig. 8. Electric power output for varying sea water temperatures (modified from [11]).

Typically, modern NPPs have about $34-40 \%$ thermal efficiency. If the cooling water is at $20^{\circ} \mathrm{C}$, the condenser temperature is about $35^{\circ} \mathrm{C}$ and corresponding saturation pressure is $0.006 \mathrm{MPa}$. The corresponding thermal efficiency of the cycle would be $32 \%$. If cooling water is at $35^{\circ} \mathrm{C}$, the condenser is at about $50^{\circ} \mathrm{C}$ and thermal efficiency of the cycle would be $30 \%$. Increase cooling water temperature by $15^{\circ} \mathrm{C}$ results in a 2 percentage-point loss of efficiency and about $6 \%$ power loss. This means for 1,450 MWh power cycle in APR-1400 the power loss would be about $90 \mathrm{MWe}$.

Efficiency of power plant which use cooling pond strongly depends on ambient air temperature. The relationship between cooling pond water use for nuclear power plants and ambient air temperature are shown in Figures 9 and 10.

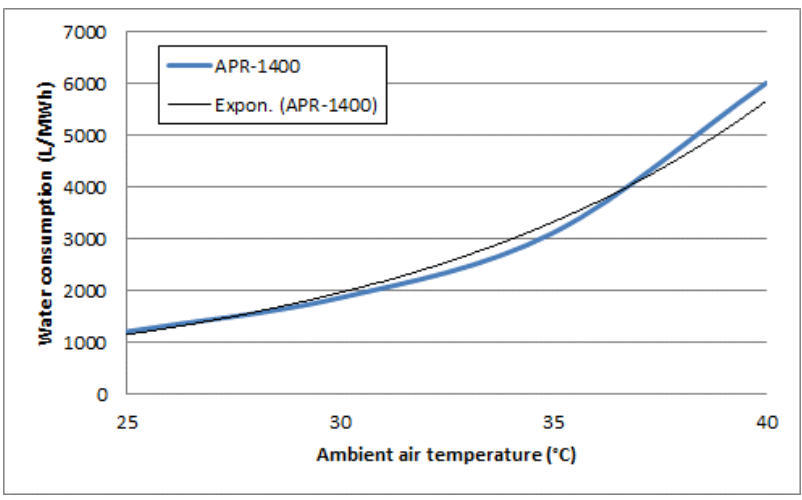

Fig. 9. Relationship between water consumption of NPP and ambient air temperature. 


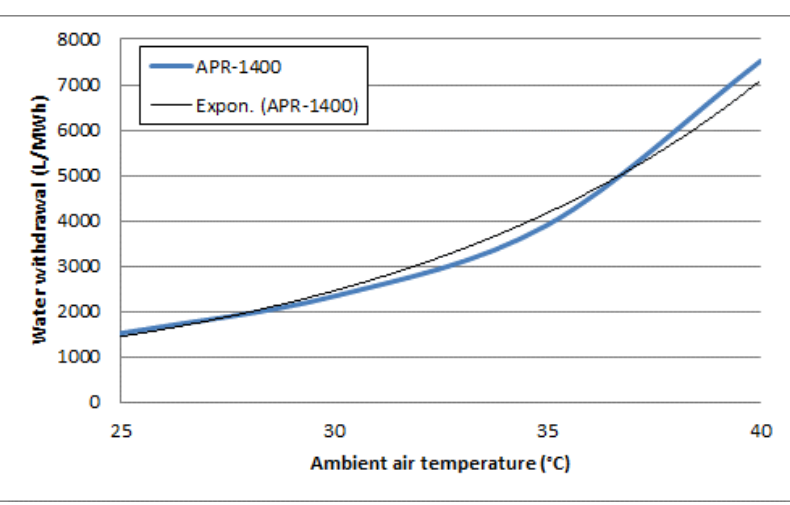

Fig. 10. Relationship between water withdrawal of NPP and ambient air temperature.

Both figures show an empirical exponential function to fit the data. The empirical relationship between water consumption (WC) and ambient air temperature $\left(T_{\text {air }}\right)$ for an APR-1400 is given by the following equation:

$$
W C=81 \exp ^{0.1062 T_{\text {air }}}
$$

The empirical relationship between water withdrawal $(W W)$ and ambient air temperature for an APR-1400 is given by the following equation:

$$
W W=101 \exp ^{0.1062 T_{\text {air }}}
$$

If the ambient air temperature is at $25^{\circ} \mathrm{C}$, the NPP water consumption would be approximately $1,217 \mathrm{~L} / \mathrm{MWh}$. The corresponding water withdrawal of NPPs is $1,521 \mathrm{~L} / \mathrm{MWh}$. If ambient air temperature is increased to $40^{\circ} \mathrm{C}$, water consumption will increase by $9-20 \%$. Similar relationships were established for power output from APR1400 NPPs and are not shown for brevity. These results are compared to studies by others and are presented in Figure 11 for water consumption and Figure 12 for water withdrawal. These show that the values are within the range of other scenarios. Most of literature are based on the light water nuclear power plants with $1000 \mathrm{MWh}$ capacity of GEN-III types with life cycle water use ranging from 7,200-231,000 L/MWh. Life Cycle Assessment methodology to estimate the impacts droughts will have on the environmental costs of nuclear power plant using cooling pond. Our study focused on APR-1400 which is GEN-III+ nuclear power plant.

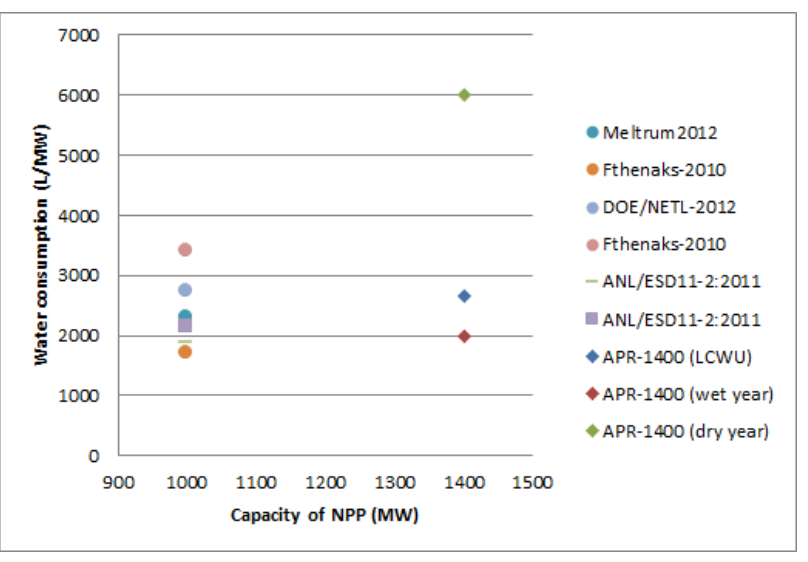

Fig. 11. Water consumption comparison between different studies [12-14].

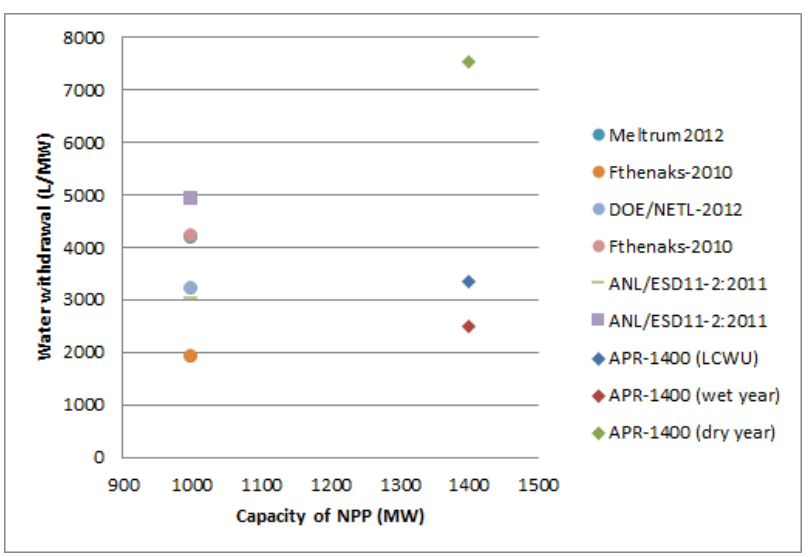

Fig. 12. Water withdrawal comparison between different studies [12-14].

In a drought year, water usage during operations for hydro and nuclear power plants increase. There is no clear data on how water use will change during other stages in the life cycle as a result of drought conditions. The relationship used to consider the effect of droughts is:

$$
L C W W=\frac{W W(\text { drought } \text { years })}{P(\text { drought years })}+\frac{W W(\text { wet } \text { years })}{P(\text { wet years })}
$$

As stated earlier, we considered droughts to occur every 4 years and took that into the power and water usage calculations. In doing so, we found that water withdrawal increased by $44 \%$ for the NPP and power output dropped about $6 \%$ for the APR1400 scenario. The output is summarized in Table 7. 
Table 7. Estimated water use by NPPs for the Mongolian scenario. Units in L/MWh.

\begin{tabular}{ll}
\hline Wet year & \\
Water consumption & 6,143 \\
Water withdrawal & 6,610 \\
Dry year & \\
Water consumption & 10,294 \\
Water withdrawal & 11,799 \\
Wet year & \\
Water consumption & 6,944 \\
Water withdrawal & 7,611 \\
\hline
\end{tabular}

\section{CONCLUSION}

As the effects of climate change are being felt all over the world, sustainability indicators such as water withdrawn per power generated are becoming more important in the decision making process for large infrastructure projects. Mongolia is one of the of the world's largest land-locked countries which has limited water resources. Mongolia has experienced a significant structural change in its energy demand. Industrial energy demand has rapidly increased in the past few years mainly due to expansion of energy intensive industries. However, local droughts in Mongolia can be quite severe, occurring on average every 4-5 years and several countries have shown droughts to interrupt nuclear and hydro power plant operations.

This study collected data and conducted analyses to estimate sustainability indicators involving water consumption and withdrawal at an APR1400 nuclear power plant. These relationships seem to show an exponential relationship between the water indicators and the ambient temperature. At an ambient temperature of $25^{\circ} \mathrm{C}$, water consumption was estimated to be about 1,200 $\mathrm{L} / \mathrm{MWh}$ and the corresponding water withdrawal of NPPs is about $1,500 \mathrm{~L} / \mathrm{MWh}$. These numbers, when compared on a plant by plant basis, seem to be within the lower bounds of other studies regarding light water nuclear power plant sustainability indicators.

Using the tools built, we try to estimate how an event such as a drought would affect water consumption and withdrawal for a nuclear power program that uses cooling ponds. Additional intermediate relationships were developed based on the estimation we estimated water consumption and withdrawal to increase $40-50 \%$. Power plant output also decreased $5-10 \%$. If we account for drought frequency in Mongolia, the life cycle water withdrawal is estimated to be $7,611 \mathrm{~L} / \mathrm{MWh}$ for the nuclear power plant under consideration. There is no clear data on how water use will change during other stages in the life cycle as a result of drought conditions. When designing and building new power plants in Mongolia, designers have to take into account the possibility of extreme drought

\section{REFERENCES}

1. Natsagdorj, L. "Drought and Heavy snow fall", BAMBY publishing, Ulaanbaatar, Mongolia. 2009.

2. DOE/NETL, An analysis of the effects of drought conditions on electric power generation in the Western United States, National Energy Technology Laboratory report, DOE/NETL-2009/1365. 2009.

3. Hutson, S.S., "Estimated use of water in the United States in 2000" Geological Survey Circular, U.S. 46pp. 2004.

4. Son, Y.K., Private communication. 2013.

5. Mudd, G.M., Diesendorf, M. Sustainability of Uranium Mining and Milling: Toward Quantifying Resources and Eco-Efficiency. Environmental Science \& Technology, 42(7), 2624-2630. 2008.

6. Gleick, P.H., Water in Crisis: A Guide to the World's Fresh Water Resources. Oxford University Press, New York. 1993.

7. Son, Y.K. Realistic assessment of concrete hydration heat effects on thermal stress development in RCB basement. Master dissertation, KEPCO Internatianal Nuclear Graduate School. 2013.

8. IAEA, Efficient water management in water cooled reactors. IAEI nuclear energy series No.NP-T-2.6. 2012.

9. Union of Concerned Scientists, issue brief "Got water?" available at www.ucsusa.org/assets/documents/nuclear_po wer/20071204-ucs-brief-got-water.pdf. 2007. (used to be 7)

10. Kam, W.L. Power plant system design. John Wiley \& Sons; 1st edition, 641pp. 1995.

11. Kim, B.K. High cooling water temperature effects on design and operational safety of NNPs in the Gulf region. Nuclear Engineering and Technology, 45(7), 961-968. 2009.

12. Fthenakis, V.M. Life-cycle uses of water in U.S. electricity generation. Renewable and 
Sustainable Energy Reviews, 14(7), 20392048. 2010.

13. Meldrum, J., Life cycle water use for electricity generation: a review and harmonization of literature estimates. Environmental Research Letters, 8(1), 015031. 2013.
14. Wu, M., Peng, M.J., Developing a Tool to Estimate Water Use in Electric Power Generation in the United States. Center for Transportation Research, Argonne National Laboratory, Report ANL/ESD/11-2. 2011. 